\title{
Document Identifier Primary Indicator
}

National Cancer Institute

\section{Source}

National Cancer Institute. Document Identifier Primary Indicator. NCI Thesaurus. Code C93810.

Specifies whether this is the main or principal document identifier. 